\title{
Perbedaan rerata hasil belajar dalam mata pelajaran perakitan PC menggunakan model pembelajaran Think Pair Share (TPS) dan Student Team Achievement Divisions (STAD) pada Siswa Kelas X TKJ di SMK Sore Tulungagung
}

\author{
Ahmad F. Al Kafi ${ }^{1}$, Dwi Prihanto ${ }^{2}$, Hary Suswanto ${ }^{3}$ \\ 1. Universitas Negeri Malang, Indonesia | AhmadFA@gmail.com \\ 2. Universitas Negeri Malang, Indonesia | dwiprihanto0524@gmail.com \\ 3. Universitas Negeri Malang, Indonesia | hary.suswanto.ft@um.ac.id
}

\begin{abstract}
Abstrak
Berdasarkan hasil observasi di SMK Sore Tulungagung, proses pembelajaran di kelas tidak semua siswa aktif dalam kegiatan diskusi karena ada siswa yang mengandalkan teman sekelompoknya, sehingga siswa yang aktif akan semakin aktif dalam kelompok dan siswa yang pasif akan semakin pasif. Oleh kerana itu, sebagian nilai siswa dalam suatu kelas mengalami ketidak tuntasan dalam mencapai kriteria kelulusan minimal (KKM) yang diterapkan sekolah tersebut. Penelitian ini bertujuan untuk mengetahui perbandingan hasil belajar mata pelajaran Perakitan PC melalui penerapan model pembelajaran Think Pair Share (TPS) dengan model pembelajaran Student Team Achievement Divisions (STAD) pada materi tata letak komponen komputer di kelas $\mathrm{X}$ program keahlian TKJ SMK Sore Tulungagung. Pengambilan sampel menggunakan teknik purposive sampling. Jenis penelitian ini adalah penelitian eksperimen dengan pendekatan kuantitatif. Metode yang digunakan pada penelitian ini adalah metode Quasi Experimental Design. Bentuk desain quasi experiment yang digunakan dalam penelitian ini adalah Nonequivalent Control Group Design.Pada penelitian ini, kelas eksperimen diberikan perlakuan berupa pembelajaran Think Pair Share (TPS), sedangkan kelas kontrol diberikan perlakuan berupa pembelajaran Student Team Achievement Divisions (STAD). Pada saat pemberian perlakuan, dilakukan juga observasi di kedua kelas untuk mengetahui aktifitas siswa yang terjadi selama proses pembelajaran. Langkah selanjutnya adalah memberikan posttest pada kelompok eksperimen dan kontrol untuk mengetahui perbedaan hasil belajar yang nampak pada kedua kelompok tersebut. Berdasarkan semua hasil penelitian dan analisis data yang dilakukan maka dapat disimpulkan sebagai berikut: (1) Rerata hasil belajar dalam mata pelajaran perakitan PC menggunakan model pembelajaran Think Pair Share (TPS) pada siswa kelas X TKJ di SMK Sore Tulungagung untuk ranah sikap dengan rata-rata nilai 85,98, ranah pengetahuan dengan rata-rata nilai 82,36 dan ranah keterampilan nilai rata-rata nilai 86,59 ; (2) Rerata hasil belajar dalam mata pelajaran perakitan PC menggunakan model pembelajaran Student Team Achievement Divisions (STAD) pada siswa kelas X TKJ di SMK Sore Tulungagung untuk ranah sikap
\end{abstract}

TEKNO Vol. 27 Issue 1, p1-14 | Jurusan Teknik Elektro, Universitas Negeri Malang, Indonesia | Maret 2017

A.F.A.Kafi., D.Prihanto., H.Suswanto. | Perbedaan rerata hasil belajar dalam mata pelajaran perakitan PC menggunakan... 


\section{TEKNO Jurnal Teknologi, Elektro, dan Kejuruan}

http://journal2.um.ac.id/index.php/tekno | ISSN 1693-8739

dengan rata-rata nilai 82,24 , ranah pengetahuan dengan rata-rata nilai 80,61 dan kontrol ranah rata-rata nilai 80,92; (3) Terdapat perbedaan signifikan efektifitas dan efisiensi rerata hasil belajar dalam mata pelajaran perakitan PC menggunakan model pembelajaran Think Pair Share (TPS) sebagai kelas experimen dan Student Team Achievement Divisions (STAD)sebagai kelas kontrol padakelas X TKJ di SMK Sore Tulungagung; (4) Efektifitas dari nilai rata-rata dari kelas kontrol adalah 79,3218 lebih rendah dari kelas eksperimen yang mendapat rata-rata 81,076. Efisiensi dapat diketahui setelah dilakukan perlakuan nilai rata-rata dari kelas eksperimen meningkat. Hal ini dibuktikan dengan nilai rata-rata dari pretest sebesar 52,0322 lalu pada posttest meningkat menjadi 81,4154.

Kata kunci

Think Pair Share, Student Team Achievement Divisions, hasil belajar

\section{Pendahuluan}

Pendidikan pada era globalisasi yang ditandai perkembangan inovasi teknologi, perlu adanya penyesuaian sistem pendidikan yang selaras dengan kebutuhan dan tuntutan dunia kerja (Syah,2006). Upaya peningkatan kualitas pendidikan perlu dilakukan secara menyeluruh meliputi aspek pengetahuan, sikap, dan keterampilan. Pengembangan aspek-aspek tersebut untuk meningkatkan dan mengembangkan kecakapan hidup siswa supaya dapat bertahan hidup, menyesuaikan diri, dan berhasil di masa mendatang (Depdiknas, 2006).

Sekolah Menengah Kejuruan (SMK) merupakan salah satu pendidikan yang terus berupaya meningkatkan kualitas pendidikan agar menghasilkan lulusan yang berkualitas, terampil, dan professional. (Winanda, 2009). SMK merupakan sekolah yang tidak hanya mengajarkan teori tetapi juga praktik (Sudjana, 2009). Dalam kesehariannya sistem pembelajaran yang diterapkan lebih banyak berhubungan dengan praktik, maka siswa SMK lebih unggul dalam praktik dibanding siswa SMA. Siswa lulusan SMK diharapkan menjadi individu yang produktif, mampu bekerja menjadi tenaga kerja menengah yang berkompeten, dan memiliki keterampilan sesuai dengan bidang keahlian mereka serta bersaing dimasyarakat (Sudjana, 2013).

Teori dan praktik pembelajaran di SMK harus dapat berjalan secara seimbang, dengan pemahaman teori yang baik dengan diiringi praktik yang terampil akan menghasilkan lulusan siswa SMK yang dapat bersaing di dunia kerja (Dimyati, 2009). Guru sebagai pelaksana pendidikan mempunyai peran yang penting dalam meningkatkan kualitas pembelajaran serta dituntut dapat mengelola proses pembelajaran secara efektif dan menciptakan kondisi belajar yang memungkinkan siswa berperan aktif, mandiri, dan kreatif (Hamalik, 2001).

Berdasarkan hasil observasi yang dilakukan di SMK Sore Tulungagung ditemukan bahwa pada mata pelajaran perawatan PC dalam proses pembelajarannya, guru menggunakan model pembelajaran adalah Student Team Achievement Divisions (STAD) (Joyce, 2009). STAD merupakan salah satu model pembelajaran cooperative learning (Slavin, 2005). Dibanding dengan model pembelajaran cooperative lainnya, STAD merupakan model pembelajaran cooperative sederhana yang memungkinkan dilaksanakan di lapangan dengan maksimal

TEKNO Vol. 27 Issue 1, p1-14 | Jurusan Teknik Elektro, Universitas Negeri Malang, Indonesia | Maret 2017

A.F.A.Kafi., D.Prihanto., H.Suswanto. | Perbedaan rerata hasil belajar dalam mata pelajaran perakitan PC menggunakan... 


\section{TEKNO Jurnal Teknologi, Elektro, dan Kejuruan}

http://journal2.um.ac.id/index.php/tekno | ISSN 1693-8739

(Majid, 2015). STAD memiliki kelebihan yaitu siswa lebih dipusatkan pada kerjasama dalam satu kelompok, tanpa melupakan pengetahuan individu (Sriwedari, 2011). Siswa dikelompokkan dengan tujuan agar dapat saling membantu dalam hal pengetahuan siswa, memotivasi siswa supaya lebih giat dalam kegiatan pembelajaran dengan diberikannya penghargaan bagi kelompok siswa yang mendapatkan nilai terbaik atau dapat menyelesaikan tugas dengan tepat waktu (Rohani, 2004).

Dalam kegiatan yang dilakukan di kelas, terlihat tidak semua siswa aktif dalam kegiatan diskusi karena ada siswa yang mengandalkan teman sekelompoknya, sehingga siswa yang aktif akan semakin aktif dalam kelompok dan siswa yang pasif akan semakin pasif. Pembelajaran yang telah dilakukan belum efektif dan keefektifan siswa masih kurang. Oleh kerana itu, sebagian nilai siswa dalam suatu kelas mengalami ketidaktutasan dalam mencapai kriteria kelulusan minimal (KKM) yang diterapkan sekolah tersebut. Untuk mengatasi permasalahan tersebut adalah dengan menerapkan model pembelajaran Think Pair Share (TPS), dimana siswa dapat melaksanakan diskusi dengan teman sebelah yang akan lebih efektif (Trianto, 2007). Dalam model pembelajaran Think Pair Share (TPS) siswa berkelompok sebanyak dua anak dan saling memeberi informasi dan digabung menjadi satu yang nantinya diinformasikan kepada teman sekelas (Prasetyo, 2012). Peserta didik harus memahami materi agar bisa menyampaikan materi dengan baik kepada teman kelompoknya. Model pemebalajaran ini dilakukan untuk mengefektifkan pembagian informasi secara efisien dan diharapkan hasil belajar siswa pada mata pelajaran perawatan PC akan naik (Vidia, 2016).

Berdasarkan latar belakang di atas, maka peneliti mengambil judul, "perbedaan rerata hasil belajar dalam mata pelajaran perakitan PC menggunakan model pembelajaran think pair share (TPS) dan student team achievement divisions (STAD) pada siswa kelas X TKJ di SMK Sore Tulungagung".

Tujuan penelitian adalah sebagai berikut: (1) Mendiskripsi rerata hasil belajar dalam mata pelajaran perakitan PC menggunakan model pembelajaran Think Pair Share (TPS) pada siswa kelas X TKJ di SMK Sore Tulungagung; (2) Mendiskripsi rerata hasil belajar dalam mata pelajaran perakitan PC menggunakan model pembelajaran Student Team Achievement Divisions (STAD) pada siswa kelas X TKJ di SMK Sore Tulungagung; (3) Mencari adanya signifikansi perbedaan rerata hasil belajar dalam mata pelajaran perakitan PC menggunakan model pembelajaran Think Pair Share (TPS) sebagai kelas experimen dan Student Team Achievement Divisions (STAD)sebagai kelas kontrol padakelas X TKJ di SMK Sore Tulungagung; (4) Mengungkap tingkat efisiensi dan efektifitas rerata hasil belajar dalam pembelajaran menggunakan model Think Pair Share (TPS) dan model Team Achievement Divisions (STAD) siswa kelas X TKJ di SMK Sore Tulungagung.

Dari hasil penelitian ini, diharapkan mampu memberikan manfaat yakni : (1) Bagi peneliti, hasil kajian ini dapat meningkatkan pemahaman, wawasan,dan pengalaman dalam model pembelajaran Think Pair Share (TPS) dan Student Team Achievement Divisions (STAD); (2) Bagi penelitian lain, hasil kajian ini dapat menambah pengetahuan dan pengalaman bagi

TEKNO Vol. 27 Issue 1, p1-14 | Jurusan Teknik Elektro, Universitas Negeri Malang, Indonesia | Maret 2017

A.F.A.Kafi., D.Prihanto., H.Suswanto. | Perbedaan rerata hasil belajar dalam mata pelajaran perakitan PC menggunakan... 


\section{TEKNO Jurnal Teknologi, Elektro, dan Kejuruan}

http://journal2.um.ac.id/index.php/tekno | ISSN 1693-8739

peneliti sehingga dapat diaplikasikan dalam kehidupan sehari-hari dan dapat memberikan wawasan lebih baik dalam model pembelajaran; (3) Bagi guru, hasil kajian ini dapatmemberikan masukan model pembelajaran terhadap guru Perakitan PC pada proses pembelajaran yang dapat meningkatkan hasil belajar; (4) Bagi siswa, hasil kajian ini dapatmenambah pengalaman belajar siswa sehingga lebih bervariasi sertauntuk meningkatkan hasil belajar siswa.

Ruang lingkup dan keterbatasan penelitian ini adalah sebagai berikut:

(1) Penelitian ini untuk mengetahui perbedaan rearata hasil belajar sebelum dan setelah diberikan perlakuan nilai pretest dan posttest. Mengetahui perbedaan nilai pretest dan posttest pada kelas eksperimen menggunakan model TPS dan kelas kontrol menggunakan STAD; (2) Variabel penelitian ini adalah hasil belajar menggunakan model pembelajaran STAD dan model pembelajaran TPS pada mata pelajaran perakitan PC di SMK Sore Tulungagung; (3) Materi pelajaran yang diambil adalah perakitan komputer menggunakan kompetensi dasar: (a) memahami peta tata letak komponen komputer dan (b) melakukan pembuatan peta tata letak komponen komputer pada siswa kelas X TKJ SMK Sore Tulungagung; (4) Sampel penelitian ini adalah duakelas X TKJ di SMK Sore Tulungagung tahun ajaran 2016-2017 dimana pada kelas A menggunakan model pembelajaran TPS dan kelas B menggunakan pembelajaran STAD.

\section{Metode}

Metode penelitian yang digunakan dalam penelitian ini adalah metode eksperimen, dimana didalam metode penelitian eksperimen juga terdapat banyak macam jenis-jenis metode. Quasi Eksperimental Design merupakan pengembangan dari true experimental design. Didalam desain ini terdpat kelompok kontrol, tetapi tidak dapat berfungsi sepenuhnya untuk mengontrol variabel-variabel luar yang mempengaruhi pelaksanaan eksperimen (Mulyasa, 2013). Didalam metode eksperimen peberian tindakan disebut treatment yang artinya pemberian kondisi yang akan dinilai pengaruhnya. Maka, penelitian ini bertujuan untuk menilai pengaruh suatu tindakan terhadap tingkah laku atau menguji ada tidaknya pengaruh tindakan itu. Dengan menggunakan Quasi Experimental Design peneliti memilih pola desain Nonequivalent Control Group Design. Pada pola nonequivalent control group design terdapat dua kelompok yang tidak dipilih secara random, yaitu kelompok eksperimen dan kelompok konrol. Pada kelompok eksperimen diberikan treatment dengan model pembelajaran TPS (Dami, Suwarto, \& Djaelani. 2013). Sedangkan kelompok kontrol diberikan treatment dengan model pembelajaran STAD. Kelas yang dijadikan sebagai subjek penelitian adalah kelas $X$ SMK Sore Tulungagung, terdiri dari dua kelompok yaitukelas $X$ TKJ 2 sebagai kelompok eksperimen dan kelas $X$ TKJ 3 sebagai kelompok kontrol.

Variable yang terlibat dalam penelitian ini terdiri dari dua variabel, yaitu:

1. Variabel bebas dalam penelitian ini adalah kelas eksperimen yang diberikan perlakuan menggunakan model pembelajaran TPS dan kelas kontrol menggunakan model pembelajaran STAD.

TEKNO Vol. 27 Issue 1, p1-14 | Jurusan Teknik Elektro, Universitas Negeri Malang, Indonesia | Maret 2017

A.F.A.Kafi., D.Prihanto., H.Suswanto. | Perbedaan rerata hasil belajar dalam mata pelajaran perakitan PC menggunakan... 


\section{TEKNO Jurnal Teknologi, Elektro, dan Kejuruan}

http://journal2.um.ac.id/index.php/tekno | ISSN 1693-8739

2. Variabel terikat dalam penelitian ini adalah hasil belajar siswa kelas $X$ Jurusan Teknik Komputer Jaringan SMK Sore Tulungagung pada mata pelajaran Perakitan PC.

Populasi dalam penelitian ini adalah siswa kelas $\mathrm{X}$ Jurusan Teknik Komputer Jaringan SMK Sore Tulungagung tahun ajaran 2015/2016. Pengambilan sampel pada penelitian ini adalah menggunakan teknik nonprobability sampling dengan teknik sampling purposive. Sampel penelitian ada dua kelas di SMK Sore Tulungagung, yaitu kelas X TKJ 2 dan kelas X TKJ 3 . Kelas ini mempunyai kemampuan yang berbeda antara siswa yang satu dengan siswa yang lain dan mempunyai rata-rata kelas yang hampir sama. Sehingga sampel yang digunakan dalam penelitian ini yaitu kelas X TKJ 2 yang berjumlah 41 siswa sebagai kelas eksperimen dan $X$ TKJ 3 yang berjumlah 39 siswa sebagai kelas kontrol. Pemasangan subjek penelitian tersebut bertujuan agar apabila terjadi perbedaan mean pada kelas kontrol dan kelas eksperimen dikarenakan perbedaan metode pembelajaran yang diterapkan.

Instrument penelitian pada penelitian kali ini terdiri dari dua macam, yaitu instrumen perlakuan dan pengukuran. Instrumen perlakuan merupakan instrumen yang digunakan untuk memberikan perlakuan pada saat penelitian. Sedangkan instrumen pengukuran merupakan instrumen yang digunakan untuk mengukur validitas dari instrumen perlakuan. Bentuk dari instrumen perlakuan yang digunakan adalah silabus, rpp, bahan ajar, job sheet, media, soal tes (pretestposttest) dan angket (kuesioner).

Instrumen-instrumen tersebut divalidasi oleh Drs. Dwi Prihanto, S.S.T., M. Pd. selaku pembimbing 1, Dr. Hary Suswanto, S.T., M.T. selaku Pembimbing 2, Eko Wahyudi, S. Kom. selaku guru SMK Sore ulungagung, Feriawan, S. Pd. selaku guru SMK Rejotangan, dan sebagai ahli materi yang memvalidasi bahan ajar, job sheet, dan soal pretest dan posttest. Uji coba instrumen skala kecil dilakukan di SMK Rejotangan pada guru TKJ dan pada siswa kelas XI TKJ yang telah menerima materi yang akan diteliti dengan jumlah siswa 36 orang. Uji coba ini dilakukan untuk menguji kevalidan dari soal pretest dan posttest.

Hasil penilaian dihitung kevalidannya dalam persen (\%) dengan menggunakan Pers. (1). Sedangkan kriteria validasi isi soal disajikan pada Tabel 1.1 (Arikunto, 2013).

$$
(\%) V S x=\frac{\text { jumlah skor penilai }}{\text { jumlah skormaksimum }} \times 100 \%
$$

Pers. (1)

Keterangan:

Vs $\mathrm{x} \quad=$ validasi isi

Tabel 1.1 Kriteria Validasi Isi Soal

\begin{tabular}{ll} 
Kriteria Validitas Isi & Nilai \\
\hline $81 \%-100 \%$ & Sangat Tinggi \\
$61 \%-80 \%$ & Tinggi \\
$41 \%-60 \%$ & Cukup \\
$21 \%-40 \%$ & Rendah \\
$0 \%-20 \%$ & Sangat Rendah \\
\hline
\end{tabular}

TEKNO Vol. 27 Issue 1, p1-14 | Jurusan Teknik Elektro, Universitas Negeri Malang, Indonesia | Maret 2017

A.F.A.Kafi., D.Prihanto., H.Suswanto. | Perbedaan rerata hasil belajar dalam mata pelajaran perakitan PC menggunakan... 


\section{TEKNO Jurnal Teknologi, Elektro, dan Kejuruan}

http://journal2.um.ac.id/index.php/tekno | ISSN 1693-8739

Dalam penelitian ini, uji validitas butir soal dihitung dengan menggunakan korelasi product moment. Rumus korelasi product moment yang digunakan Pers. (2) (Arikunto, 2013).

$$
r_{x y}=\frac{n \sum x y-\left(\sum x\right)\left(\sum y\right)}{\sqrt{\ln \sum x^{2}-\left(\sum x^{2}\right) H\left(n y^{2}-\left(\sum y\right)^{22}\right.}}
$$

Keterangan:

$r_{x y}=$ Koefisien korelasi antara variabel $\mathrm{x}$

dengan variabel y

$\mathrm{n} \quad=$ Jumlah subjek penelitian / responden

$\mathrm{x} \quad=$ skor butir soal

$\mathrm{y} \quad=$ jumlah total

Pengujian taraf validitas tiap butir soal dibandingkan dalam tabel $r$ Product Moment pada taraf signifikan 0,05.

a. Soal dikatakan valid apabila $r_{\text {hitung }} \geq r_{\text {tabel }}$ pada taraf signifikan 0,05 .

b. Soal dikatakan tidak valid apabila $r_{\text {hitung }} \leq r_{\text {tabel }}$ pada taraf signifikan 0,05 .

Selain menggunakan persamaan 3.2, perhitungan validitas butir soal dilakukan dengan bantuan aplikasi SPSS Statistics melalui menu Analyze Correlate lalu pilih Bivariant. Butir soal dikatakan valid jika nilai Sig $(p)<0,05$.

Hasil uji validitas soal didapatkan 25 soal yang valid dan 17 soal tidak valid. Dari 25 soal yang valid dipilih 21 soal yang mewakili semua indikator, sehingga soal yang digunakan untuk penelitian yaitu soal nomor $2,3,5,9,10,12,13,15,18,20,22,23,25,27,29,32,34,35,38$, 40, dan 42.

Reliabilitas merujuk pada satu pengertian bahwa suatu instrumen cukup dapat dipercaya untuk digunakan sebagai alat pengumpul data karena instrumen tersebut sudah baik. Uji reliabilitas tes dapat dihitung menggunakan rumus Alpha Crounbach.

Hasil uji reliabilitas tersebut akan diklarifikasikan pada Tabel 1.2 (Arikunto, 2013).

Tabel 1.2 Kriteria uji reliabilitas Kriteria Uji Reliabilitas

$0,00-0,20$

$0,21-0,40$

$0,41-0,60$

$0,61-0,80$

$0,81-1,00$

\section{Klasifikasi}

reliabilitas sangat rendah

reliabilitas rendah

reliabilitas cukup

reliabilitas tinggi

reliabilitas sangat tinggi

Hasil uji reliabilitas soal dengan software SPSS menggunakan rumus alpha. Dari hasil analisis menggunakan software SPSS diketahui bahwa nilai reliabilitas dari 25 soal tes yang mewakili semua indikator adalah 0,860 . Berdasarkan nilai alpha sebesar 0,831 maka dapat

TEKNO Vol. 27 Issue 1, p1-14 | Jurusan Teknik Elektro, Universitas Negeri Malang, Indonesia | Maret 2017

A.F.A.Kafi., D.Prihanto., H.Suswanto. | Perbedaan rerata hasil belajar dalam mata pelajaran perakitan PC menggunakan... 


\section{TEKNO Jurnal Teknologi, Elektro, dan Kejuruan}

http://journal2.um.ac.id/index.php/tekno | ISSN 1693-8739

disimpulkan 21 soal tes yang dipilih dan digunakan untuk penelitian bisa dikatakan reliabel atau dapat dipercaya untuk digunakan sebagai alat pengumpulan data.

Teknik analisis data pada penelitian ini terdiri dari uji prasyarat analisis, uji kesamaan dua rata-rata, uji hipotesis, uji efisiensi dan uji efektifitas.

Dalam uji prasyarat analisis dilakukan uji normalitas dan homogenitas. Uji normalitas digunakan untuk melakukan pengujian data observasi, apakah data tersebut berdistribusi normal atau tidak (Sarwono, 2012). Data yang diuji adalah hasil pretest siswa. Uji statistik yang digunakan yaitu uji skewness dan kurtosis menggunakan SPSS 21. Kriteria normalitas sebagai berikut:

1) Bila nilai skewness dibagi dengan standart error skewness dan nilai kurtosis dibagi dengan standart error kutrosis menghasilkan nilai yang berada diantara rentang +2 dan -2 , maka dapat dikatakan bahwa distribusi data adalah normal.

2) Bila nilai skewness dibagi dengan standart error skewness dan nilai kurtosis debagi dengan standart error kurtosis menghasilkan nilai yang tidak berada diantara +2 dan -2 , maka dapat dikatakan bahwa distribusi data adalah tidak normal.

Uji homogenitas digunakan untuk menguji kesamaan beberapa bagian sampel, yakni seragam tidaknya variansi sampel-sampel yang diambil dari populasi yang sama. Uji homogenitas varians dalam penelitian ini menggunakan uji $F$ yang ditunjukkan pada Pers. (3).

$$
\mathrm{F}_{\text {hitung }}=\frac{\text { varians terbesar }}{\text { varians terkecil }} \quad \text {. Pers.(3) }
$$

Pengambilan Keputusan:

Dasar pengambilan keputusan (uji varian menggunakan uji satu sisi), berupa;

a) Jika probabilitas $>0,05$, maka $\mathrm{H}_{0}$ diterima

b) Jika probabilitas $<0,05$, maka $\mathrm{H}_{0}$ ditolak

Uji kesamaan dua rata-rata ini digunakan untuk mengetahui apakah kemampuan awal kedua sampel sama atau tidak. Uji statistik yang digunakan adalah uji Independent sample $t$ test dengan menggunakan data kemampuan awal siswa yang diperoleh dari nilai pretest sebelum pembelajaran berlangsung. Uji t dengan independent sample test pada kolom t-test di bagian Asymp. Sig dengan bantuan SPSS melalui menu Analyze $\rightarrow$ Compare means $\rightarrow$ Independent Sample T Test.

Uji hipotesis untuk mengetahui perbedaan rerata hasil belajar ranah sikap, hasil belajar ranah pengetahuan, dan hasil belajar ranah keterampilan pada siswa yang menggunakan model pembelajaran STAD dan model pembelajaran TPS yang ditunjukkan pada Pers. (4) (Subana, 2000).

TEKNO Vol. 27 Issue 1, p1-14 | Jurusan Teknik Elektro, Universitas Negeri Malang, Indonesia | Maret 2017

A.F.A.Kafi., D.Prihanto., H.Suswanto. | Perbedaan rerata hasil belajar dalam mata pelajaran perakitan PC menggunakan... 


\section{TEKNO Jumal Teknologi, Eektro, dan Kejuruan}

http://journal2.um.ac.id/index.php/tekno | ISSN 1693-8739

$$
t=\frac{\bar{x}_{E}-\bar{x}_{K}}{d s g \sqrt{\frac{1}{n_{1}}+\frac{1}{n_{2}}}}
$$

Keterangan:

$\bar{x}_{E}=$ rata-rata data kelompok kontrol

$\bar{x}_{K}=$ rata-rata data kelompok eksperimen

$d s g=$ nilai deviasi standar gabungan

$\mathrm{n}_{1}$ = banyaknya

Pengambilan keputusan hipotesis:

- Jika $t_{\text {hitung }}<t_{\text {tabel }}$ maka Ho di terima

- Jika $t_{\text {hitung }}>t_{\text {tabel }}$ maka Ho di tolak

Pengujian Uji t paired sample pada penelitian ini menggunakan bantuan SPSS dengan independent sample test pada kolom $t$-test pada bagian Asymp.Sig melalui menu Analyze $\rightarrow$ Compare Means $\rightarrow$ Independent Samples $T$ test.

Pengambilan keputusan hipotesis:

- $\quad$ Jika nilai signifikansi $(p)>0.05$, maka Ho diterima

- Jika nilai signifikansi $(p)<0.05$, maka Ho ditolak

Uji efisiensi ini dilakukan terhadap dua sampel yang berpasangan (paired). Sampel yang berpasangan diartikan sebagai sebuah sampel dengan subyek yang sama namun mengalami dua perlakuan atau pengukuran yang berbeda. Uji ini dilakukan untuk mengetahui apakah ada perbedaan sebelum dan sesudah diberikan perlakuan. Rumus untuk menguji sampel yang berpasangan Pers. (5) (Sugiyono, 2013).

$$
t=\frac{\overline{X_{1}}-\overline{X_{2}}}{\sqrt{\frac{s_{1}^{2}}{n_{1}}+\frac{s_{2}^{2}}{n_{2}}-2 r\left(\frac{s_{1}}{\sqrt{n_{1}}}\right)\left(\frac{s_{2}}{\sqrt{n_{2}}}\right)}}
$$

Keterangan:

$X_{1}$ : Rata-rata skor kelompok eksperimen

$X_{2}$ : Rata-rata skor kelompok kontrol

$S_{1}^{2}$ : Varian kelompok eksperimen

$S_{2}^{2}$ : Varian kelompok kontrol

$\mathrm{n}_{1}$ : Jumlah siswa kelompok eksperimen

$\mathrm{n}_{2}$ : Jumlah siswa kelompok kontrol

$r$ : Korelasi antara data dua kelompok

$\mathrm{S}_{1}$ : Simpangan baku kelompok 


\section{TEKNO Jumal Teknologi, Eektro, dan Kejuruan}

http://journal2.um.ac.id/index.php/tekno | ISSN 1693-8739

eksperimen

$\mathrm{S}_{2}:$ Simpangan baku kelompok kontrol

Hipotesis:

$\mathrm{H}_{0}$ : Kedua rata-rata populasi adalah

identik

(rata-rata populasi kelas $\mathrm{X} \mathrm{TKJ}_{\text {Eksperimen }}$ sebelum dan sesudah perlakuan adalah sama)

$\mathrm{H}_{1}$ : Kedua rata-rata populasi adalah tidak identik

(rata-rata populasi kelas $\mathrm{X} T \mathrm{TKJ}_{\text {Eksperimen }}$ sebelum dan sesudah perlakuan adalah tidak sama)

Dasar pengambilan keputusan berdasarkan nilai probabilitas:

- Jika probabilitas $>0,05$ maka $\mathrm{H}_{0}$ diterima

- Jika probabilitas $<0,05$ maka $\mathrm{H}_{0}$ ditolak

Untuk uji dua sisi, setiap sisi dibagi 2, sehingga menjadi:

- $\quad$ Angka probabilitas $/ 2>0,025, \mathrm{H}_{0}$ diterima

- $\quad$ Angka probabilitas $/ 2<0,025, \mathrm{H}_{0}$ ditolak

Uji efektifitas digunakan untuk mengetahui apakah terdapat perbedaan hasil belajar antara kelas eksperimen yang diberikan treatment dengan kelas kontrol yang tidak diberikan treatment. Uji efektifitas dilakukan dengan menggunakan uji $t$ dua sample. Pada dasarnya uji $t$ mensyaratkan adanya kesamaan dari dua populasi diuji. Uji $t$ dua sampel dilakukan dalam dua tahapan.

Tahapan pertama adalah menguji apakah varian dari dua populasi bisa dianggap sama. Pengujian asumsi kesamaan varian dilakukan melalui uji $F$. Rumus Uji $F$ dapat dilihat pada Pers. (6) (Subana, 2000).

$$
\mathrm{F}=\frac{\text { Varians Besar }}{\text { Varians Kecil }}
$$

Hipotesis:

$\mathrm{H}_{0}$ : Kedua varian populasi adalah identik

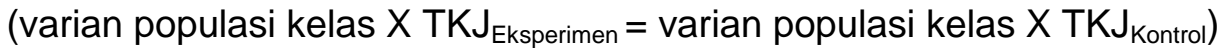

$\mathrm{H}_{1}$ : Kedua varian populasi adalah tidak identik

(varian populasi kelas $X \mathrm{TKJ}_{\text {Eksperimen }} \neq$ varian populasi kelas $X \mathrm{TKJ}_{\text {Kontrol }}$ )

Pengambilan Keputusan:

Dasar pengambilan keputusan (uji varian menggunakan uji satu sisi), berupa:

- Jika probabilitas $>0,05$, maka $\mathrm{H}_{0}$ diterima

- Jika probabilitas $<0,05$, maka $\mathrm{H}_{0}$ ditolak

TEKNO Vol. 27 Issue 1, p1-14 | Jurusan Teknik Elektro, Universitas Negeri Malang, Indonesia | Maret 2017

A.F.A.Kafi., D.Prihanto., H.Suswanto. | Perbedaan rerata hasil belajar dalam mata pelajaran perakitan PC menggunakan... 


\section{TEKNO Jurnal Teknologi, Elektro, dan Kejuruan}

http://journal2.um.ac.id/index.php/tekno | ISSN 1693-8739

Tahap kedua adalah analisis dengan memakai uji t atau t-Test untuk mengetahui apakah rata-rata pretest kelas $X$ TKJ eksperimen dan kelas $X$ TKJ kontrol adalah berbeda secara signifikan. Rumus untuk uji t dapat dilihat pada Pers. (7) (Sugiyono, 2013).

$$
t=\frac{\overline{X_{1}}-\overline{X_{2}}}{\sqrt{\frac{\left(n_{1}-1\right) s_{1}^{2}+\left(n_{2}-1\right) s_{2}^{2}}{n_{1}+n_{2}-2}\left(\frac{1}{n_{1}}\right)\left(\frac{1}{n_{2}}\right)}}
$$

Pers, (7)

Keterangan:

$\overline{X_{1}}$ : Rata-rata skor kelompok eksperimen

$\overline{X_{2}}$ : Rata-rata skor kelompok kontrol

$s_{1}^{2}$ : Varian kelompok eksperimen

$s_{1}^{2}$ : Varian kelompok kontrol

$n_{1}$ : Jumlah siswa kelompok eksperimen

$n_{2}$ : Jumlah siswa kelompok kontrol

Hipotesis:

$\mathrm{H}_{0}$ : Kedua rata-rata populasi adalah identik

(rata-rata populasi kelas $X \mathrm{TKJ}_{\text {Eksperimen }}=$ rata-rata populasi kelas $\left.\mathrm{X} T K \mathrm{JK}_{\text {Kontrol }}\right)$

$\mathrm{H}_{1}$ : Kedua rata-rata populasi tidak identik

(rata-rata populasi kelas $X T K J_{\text {Eksperimen }}$ rata-rata populasi kelas $X \mathrm{TKJ}_{\text {Kontrol }}$ )

\section{Hasil}

Hasil analisis dari penelitian ini meliputi analisis data dari uji coba instrumen, data kemampuan awal dan data kemampuan akhir siswa pada kelas eksperimen dan kelas kontrol.

Dari hasil pretest tersebut dapat diketahui nilai rata-rata dari kedua kelas adalah 54,06 dengan nilai maksimum 71,43 dan nilai minimum 38,10. Rata-rata dari kelas kontrol adalah 56,26 dengan nilai maksimum 71,43 dan nilai minimum 42,86. Rata-rata dari kelas eksperimen adalah 52,03 dengan nilai maksimum 66.67 dan nilai minimum 38,10. Analisis data kemampuan awal siswa terdiri dari uji prasyarat analisis, yaitu uji normalitas dan uji validitas. Di dalam uji validitas terdapat dua tahap yaitu tahap pertama uji homogenitas dan tahap ke dua uji kesamaan dua rata-rata.

Berdasarkan hasil uji normalitas tiap kelas dapat disimpulkan, bahwa:

a. Skewness kurva pretest kelas eksperimen adalah 0,223 dengan Standard Error sebesar 0,369. Kurtosis kurva adalah -0,663 dengan Standard Error sebesar 0,724. Dari data tersebut diperoleh rasio Skewness dan rasio Kurtosis dengan membagi nilai Skewness dan Kurtosis dengan Standard Error-nya. 


\section{TEKNO Jurnal Teknologi, Elektro, dan Kejuruan}

http://journal2.um.ac.id/index.php/tekno | ISSN 1693-8739

Rasio Skewness sebesar: $\frac{0,223}{0,369}=0,604$

Rasio Kurtosis sebesar: $\frac{-0,663}{0,724}=-0,915$

b. Skewness kurva pretest kelas kontrol adalah 0,184 dengan Standard Error sebesar 0,383. Kurtosis kurva adalah -0,402 dengan Standard Error sebesar 0,750. Dari data tersebut diperoleh rasio Skewness dan rasio Kurtosis dengan membagi nilai Skewness dan Kurtosis dengan Standard Error-nya.

Rasio Skewness sebesar: $\frac{0,184}{0,383}=0,604$

Rasio Kurtosis sebesar: $\frac{-0,402}{0,750}=-0,915$

Dari hasil tersebut terlihat bahwa rasio Skewness dan Kurtosis berada pada kisaran -2 sampai +2 , sehingga bisa disimpulkan bahwa data terdistribusi secara normal.

Berdasarkan hasil rata-rata uji kemampuan awal dapat disimpulkan, bahwa:

a. Terlihat ringkasan statistik dari kedua kelompok, yaitu jumlah siswa kelas eksperimen sebanyak 41 siswa dan jumlah siswa kelas kontrol sebanyak 38 siswa. Hasil pretest pada kelas eksperimen memiliki nilai rata-rata pretest 52,0322 dan nilai rata-rata pretest pada kelas kontrol adalah 56,2645.

b. Terdapat perbedaan antara nilai rata-rata kelas eksperimen dengan nilai rata-rata kelas kontrol yang tidak beda jauh, akan tetapi nilai pretest pada kelas kontrol lebih besar dibandingkan dengan kelas eksperimen.

Uji t dua sampel dilakukan dalam dua tahapan. Tahapan pertama yaitu uji homogenitas. Uji homogenitas ini untuk menguji apakah varian dari dua populasi bisa dianggap sama. Setelah itu baru dilakukan tahapan kedua yaitu uji kesamaan dua rata-rata. Uji kesamaan dua rata-rata ini untuk mengetahui apakah kemampuan awal bisa dianggap sama.

Tahap pertama dilakukan pengujian apakah ada beberapa bagian sampel yang seragam dari variansi sampel yang diambil pada kelas X TKJ 3 (kelas kontrol) dan kelas X TKJ 2 (kelas eksperimen). $\mathrm{F}$ hitung untuk pretest dengan Equal variances assumed (diasumsikan kedua varian sama) adalah 0,001 dengan probabilitas 0,977 . Karena probabilitas $F$ hitung lebih besar dari 0,05 atau dengan kata lain 0,977 >0,05, maka $\mathrm{H}_{0}$ diterima atau dapat dikatakan kedua varian identik sama. Karena kesamaan yang nyata dari kedua varian tersebut, maka penggunaan varian untuk membandingkan rata-rata populasi dengan $t$-Test sebaiknya menggunakan dasar Equal variances assumed (diasumsikan kedua varian sama).

Tahap kedua adalah analisis dengan memakai uji $t$ untuk mengetahui apakah rata-rata pretest kelas X TKJ 3 (kontrol) dan kelas X TKJ 2 (eksperimen) terdapat perbedaan, t hitung untuk pretest dengan Equal variances assumed (diasumsikan kedua populasi sama) adalah 2,607 dengan probabilitas 0,011. Jika menggunakan paket program statistik, untuk memutuskan apakah $\mathrm{H}_{0}$ ditolak atau diterima, peneliti tinggal membandingkan nilai $p$ dengan nilai $\alpha$. Berdasarkan Tabel 4.4, diperoleh $p$ lebih besar dari $\alpha$, atau dengan kata lain 0,011> 0,05, maka $\mathrm{H}_{0}$ diterima.

TEKNO Vol. 27 Issue 1, p1-14 | Jurusan Teknik Elektro, Universitas Negeri Malang, Indonesia | Maret 2017

A.F.A.Kafi., D.Prihanto., H.Suswanto. | Perbedaan rerata hasil belajar dalam mata pelajaran perakitan PC menggunakan... 


\section{TEKNO Jurnal Teknologi, Elektro, dan Kejuruan}

http://journal2.um.ac.id/index.php/tekno | ISSN 1693-8739

Analisis nilai sikap diambil dari penilaian observasi, nilai pengetahuan diambil dari penilaian hasil diskusi dan soal evaluasi dan nilai keterampilan diambil dari penilaian unjuk kerja pada kelas eksperimen dan kelas kontrol (Shirran, 2008).

Pada kelas eksperimen untuk ranah sikap nilai minimumnya adalah 75,00 dan nilai maksimumnya adalah 100,00 dengan rata-rata nilai 85,98 . Pada ranah pengetahuan nilai minimumnya adalah 68 dan nilai maksimumnya adalah 93 dengan rata-rata nilai 82,36 . Pada ranah keterampilan nilai minimumnya adalah 75,00 dan nilai maksimumnya adalah 100,00 dengan rata-rata nilai 86,59 .

Pada kelas kontrol ranah sikap nilai minimumnya adalah 50,00 dan nilai maksimumnya adalah 100,00 dengan rata-rata nilai 82,24 . Pada ranah pengetahuan nilai minimumnya adalah 68 dan nilai maksimum adalah 91 dengan rata-rata nilai 80,61 . Pada ranah keterampilan nilai minimumnya adalah 50,00 dan nilai maksimum adalah 100,00 dengan rata-rata 80,92.

Uji efektifitas digunakan untuk mengetahui apakah terdapat perbedaan hasil belajar antara kelas eksperimen yang diberikan perlakuan model pembelajaran TPS dengan kelas kontrol yang diberikan perlakuan model pembelajaran STAD. Nilai rata-rata kelas eksperimen adalah 81,076 dan kelas kontrol adalah 79,3218. Dengan demikian, nilai posttest kelas eksperimen lebih tinggi dibandingkan kelas kontrol.

Uji efisiensi dilakukan untuk mengetahui pengaruh model pembelajaran Think Pair Share terhadap hasil belajar siswa yaitu apakah ada peningkatan hasil belajar yang signifikan setelah diberi perlakuan. Uji ini dilakukan dengan menganalisis data hasil pretest dan posttest kelas eksperimen. statistik dari 41 siswa kelas X TKJ 2 eksperimen sebelum dan sesudah di beri perlakuan. Untuk nilai rata-rata siswa sebelum perlakuan mempunyai nilai rata-rata sebesar 52,0322 sedangkan setelah perlakuan mempunyai nilai rata-rata sebesar 81,4154 . Korelasi menghasilkan angka sebesar 0,636 dengan nilai probabilitas dibawah 0,05 (lihat nilai signifikansi output sebesar 0,000$)$. Hal ini menyatakan bahwa ada korelasi sebelum dan sesudah perlakuan, t hitung adalah 29,491 dengan probabilitas 0,000 . Untuk uji dua sisi, angka probabilitas adalah $0,000 / 2=0,000$. Karena $0,000<0,025$, maka $\mathrm{H}_{0}$ ditolak.

\section{Kesimpulan}

Berdasarkan semua hasil penelitian dan analisis data yang dilakukan maka dapat disimpulkan sebagai berikut:

1. Rerata hasil belajar dalam mata pelajaran perakitan PC menggunakan model pembelajaran Think Pair Share (TPS) pada siswa kelas X TKJ di SMK Sore Tulungagung untuk ranah sikap dengan rata-rata nilai 85,98 , ranah pengetahuan dengan rata-rata nilai 82,36 sebagian besar data nilai siswa terentang dari $(86-93)$, dengan frekuensi 17 atau sebesar $41 \%$ dan terkategori "Sangat Tinggi" dan ranah keterampilan nilai rata-rata nilai 86,59.

2. Rerata hasil belajar dalam mata pelajaran perakitan PC menggunakan model pembelajaran Student Team Achievement Divisions (STAD) pada siswa kelas X TKJ di SMK Sore Tulungagung untuk ranah sikap dengan rata-rata nilai 82,24 , ranah pengetahuan dengan

TEKNO Vol. 27 Issue 1, p1-14 | Jurusan Teknik Elektro, Universitas Negeri Malang, Indonesia | Maret 2017

A.F.A.Kafi., D.Prihanto., H.Suswanto. | Perbedaan rerata hasil belajar dalam mata pelajaran perakitan PC menggunakan... 


\section{TEKNO Jurnal Teknologi, Elektro, dan Kejuruan}

http://journal2.um.ac.id/index.php/tekno | ISSN 1693-8739

rata-rata nilai 80,61 sebagian besar data nilai siswa terentang dari $(74-79)$, dengan frekuensi 14 atau sebesar 37\% dan terkategori "Sedang/ Cukup" dan kontrol ranah rata-rata nilai 80,92 .

3. Terdapat perbedaan signifikan efektifitas dan efisiensi rerata hasil belajar dalam mata pelajaran perakitan PC menggunakan model pembelajaran Think Pair Share (TPS) sebagai kelas experimen dan Student Team Achievement Divisions (STAD)sebagai kelas kontrol padakelas X TKJ di SMK Sore Tulungagung.

4. Efektifitas dari model pembelajaran Think Pair Share diperoleh dari perbandingan antara nilai posttest kelas kontrol dengan posttest kelas eksperimen, bahwa nilai rata-rata dari kelas kontrol adalah 79,3218 lebih rendah dari kelas eksperimen yang mendapat rata-rata 81,076. Efisiensi dari model pembelajaran Think Pair Share diperoleh dari perbandingan antara nilai pretest dengan posttest dari kelas eksperimen, dapat diketahui setelah dilakukan perlakuan nilai rata-rata dari kelas eksperimen meningkat. Hal ini dibuktikan dengan nilai rata-rata dari pretest sebesar 52,0322 lalu pada posttest meningkat menjadi 81,4154 .

Berdasarkan hasil penelitian yang telah dilakukan, dapat diberikan saran sebagai berikut:

1. Dengan model pembelajaran TPS, Guru mata pelajaran Perakitan PC jurusan TKJ di SMK Sore Tulungagung dapat mengimplementasikan kegiatan serupa di mata pelajaran yang lain dalam peningkatan hasil belajar siswa.

2. Guru mata pelajaran Perakitan PC jurusan TKJ di SMK Sore Tulungagung dapat mengimplementasikan model pembelajaran TPS, karena telah terbukti dapat meningkatkan hasil belajar siswa pada ranah sikap, pengetahuan dan keterampilan.

3. Pemilihan model pembelajaran yang akan digunakan pada siswa juga penting melihat keadaan kelas dan mata pelajaran sehingga model pembelajaran yang diterapkan dapat meningkatkan hasil belajar siswa.

\section{Daftar Rujukan}

Arikunto, Suharsimi. 2013. Dasar-dasar Evaluasi Pendidikan. Jakarta: Bumi Aksara.

Dami, Suwarto, \& Djaelani. 2013. Perbedaan Pengaruh antara Model Kooperatif Tipe TPS dan STAD terhadap Hasil Belajar IPS. (Online), (http://eprints.uns.ac.id/14095/1/2167-4912-1PB.pdf), diakases pada 22 Desember 2015

Dimyati. 2009. Belajar dan Pembelajaran. Jakarta: PT. Rineka Cipta Hamalik, Oemar. 2001. Proses Belajar Mengajar. Jakarta: Bumi Aksara.

Joyce, B. 2009. Models of Teaching Model-model Pengajaran. Yogyakarta: Pustaka Pelajar.

Majid, Abdul. 2015. Strategi Pembelajaran. Bandung: Remaja Rosdakarya.

TEKNO Vol. 27 Issue 1, p1-14 | Jurusan Teknik Elektro, Universitas Negeri Malang, Indonesia | Maret 2017

A.F.A.Kafi., D.Prihanto., H.Suswanto. | Perbedaan rerata hasil belajar dalam mata pelajaran perakitan PC menggunakan... 


\section{TEKNO Jurnal Teknologi, Elektro, dan Kejuruan}

http://journal2.um.ac.id/index.php/tekno | ISSN 1693-8739

Mulyasa. 2013. Pengembangan dan Implementasi Kurikulum 2013. Bandung: PT. Remaja Rosdakarya.

Prasetyo, Teguh. 2012. Penerapan Pembelajaran Kooperatif Think Pair Share untuk Meningkatkan Hasil Belajar, Kreativitas, Minat dan Motivasi Belajar Ekonomi Siswa Kelas X SMAN 2 Bojonegoro.Tesis. Jurusan Pendidikan Ekonomi, Program Pascasarjana Universitas Negeri Malang.

Rohani, Ahmad. 2004. Pengelolaan Pengajaran. Jakarta: PT Rineka Cipta.

Shirran, Alex. 2008. Evaluating Students. Jakarta: Grasindo.

Sriwedari, Tatik. 2011. Pengaruh penerapan pembelajaran kooperatif STAD dan TPS terhadap kemampuan berpikir kritis, keterampilan proses, dan hasil belajar kognitif biologi siswa kelas VIII SMP Negeri 1 Malang.Tesis. Program Studi Pendidikan Dasar, Program Pascasarjana Universitas Negeri Malang.

Sudjana, Nana. 2009. Penilaian Hasil Proses Belajar Mengajar. Bandung: PT. Remaja Rosdakarya offset

Sudjana, Nana. 2013. Penilaian Hasil Proses Belajar Mengajar. Bandung: PT. Remaja Rosdakarya.

Sugiyono. 2013. Metode Penelitian Kuantitatif Kualitatif dan R\&D. Bandung: Alfabeta.

Slavin, Robert E. 2005. Cooperative Learning Teori, Riset, dan Praktik.Bandung: Penerbit Nusa Media.

Syah, Muhibbin. 2006. Psikologi Pendidikan dengan Pendekatan Baru. Bandung: PT Remaja Rosdakarya.

Trianto. 2007. Model-model Pembelajaran Berorentasi Konstruktivistik. Jakarta: Prestasi Pustaka.

Vidia \& Riwayati. 2016. Perbedaan Hasil Belajar Siswa dengan menggunakan Model Pembelajaran Kooperatif Tipe Think Pair Share dengan Tipe Student Teams Achievement Division pada Materi Pokok Ekosistem. (Online), (http://jurnal.unimed.ac.id/2012/index.php/pelita/article/viewFile/4056/3609), diakases pada 12 Juli 2016

Winanda, Ari. 2009. Penerapan pembelajaran think pair share (TPS) untuk meningkatkan hasil belajar siswa pada materi segitiga di kelas VII-C SMP Negeri 2 Besuk tahun ajaran 2009/2010.Tesis. Program Studi Pendidikan Matematika, Program Pascasarjana Universitas Negeri Malang. 